\title{
INTERIM COSTS IN DIVORCE ACTIONS
}

On a recent application for interim costs in a divorce action in Edmonton Chambers, the presiding Judge decided he did not have jurisdiction under the Divorce Act to grant such relief.

The amount which could have been awarded was relatively small and therefore an appeal was probably precluded. However, in pondering that incident, the writer was unable to appreciate the Judge's decision (there were no reasons) and accordingly began to research the matter - which has resulted in this note.

The history of interim costs in divorce actions, at common law, originated at a time when the wife, in the view of the common law, could have no property of her own. Thus, the Courts, in order to help such a poor (and second-class) creature, allowed her security for her costs so that she might prosecute or defend the action. This amount could be varied from time to time. ${ }^{1}$ Later this basis changed and was finally based upon the concept of the implied authority of a wife to pledge her husband's credit for necessities. ${ }^{2}$

The practice in Alberta has always allowed the wife interim costs or security therefore, ${ }^{8}$ and this practice continued up to (and after) the advent of the Divorce Act.

Has the Divorce Act changed the practice of the Alberta Supreme Court? Looking at the Divorce Act, s. 19 (1) reads:

19 (1) A court or court of appeal may make rules of court applicable to any proceedings under this Act within the jurisdiction of that court, including, without restricting the generality of the foregoing, rules of court

(a) regulating the pleading, practice and procedure in the court, including the addition of persons as parties to the proceedings;

(b) regulating the sittings of the court;

(c) respecting the fixing and awarding of costs;

(d) providing for the registration and enforcement of orders made under this Act including their enforcement after death; and

(e) prescribing and regulating the duties of officers of the court and any other matter considered expedient to attain the ends of justice and carry into effect the purposes and provisions of this Act.

It can be seen that section $19(1)(\mathrm{a})$, (c) and (e) are important to this discussion. In addition, the Supreme Court has the power to regulate its own practice and procedure and to make rules pertaining thereto, subject to the authorization of the Lieutenant Governor in Council.s Pursuant to that power, the Alberta Rules of Court provide: ${ }^{\circ}$

577A. The court may at any time after a petition for divorce has been presented, and if necessary from time to time, make such order as it thinks fit, for payment of or security for the costs of either spouse.

This rule, it is suggested, is merely the restatement of the powers and practice of the court prior to the Divorce Act (with the exception that it now also allows the husband to apply for such costs from the wife). ${ }^{7}$

1 Gilroy v. Gilroy [1914] P. 122, 83 L.J.P. 49, 110 L.T. 601.

2 Ottaway v. Hamilton [1877-78] 3 C.P.D. 393, 47 L.J.C.P. 725, 37 L.T. 925.

${ }^{8}$ Rousseau v. Rousseau [1928] 1 W.W.R. 694 (Alta.S.C.).

- Divorce Act, S.C. 1967-68, c. 24.

5 Judicature Act, R.S.A. 1970, c. 193, s. 39; Alta. Rules of Court 964.

- It should be noted that Alta. Rule 396; which sets out the conditions precedent for an application for interim alimony or costs, applies only to actions brought by the wife for alimony limited to that relief alone and not in divorce actions: Rousseau v. Rousseau, supra; n. 3 at 696.

7 Rousseau v. Rousseau, supra, n. 3 at 699. 
Are the Rules applicable to proceedings under the Divorce Act?

In Sutt v. Sutt, ${ }^{8}$ Schroeder J.A., of the Ontario Court of Appeal, stated: ${ }^{\ominus}$

The new Matrimonial Causes Rules were passed not only by the Ontario Rules Committee but by the Judges, as specifically provided for by s. 19(1) of the [Divorce] Act. Having been thus enacted they clearly become federal rules of practice and procedure regulating the pleading, practice and procedure and all other matters pertaining to proceedings for divorce and incidental relief founded on the provision of the [Divorce] Act. ....

It is vitally important to keep in mind the essential distinction between substantive and procedural law. Substantive law creates rights and obligations and is concerned with the ends which the administration of justice seeks to attain, whereas procedural law is the vehicle providing the means and instruments by which those ends are attained. It regulates the conduct of Courts and litigants in respect of the litigation itself whereas substantive law determines their conduct and relations in respect of the matters litigated.

Perhaps there is some doubt because section 10 of the Divorce Act, marginally noted as "Interim Orders", does not specifically refer to interim costs. This point was considered by the Master in Ontario in Boerop v. Boerop: 10 $^{10}$

While it is true that there is no reference to interim disbursements in $s .10$ of the Divorce Act, it is to be observed that s. $19(1)(c)$ of that Act provides for the making of rules of Court applicable to any proceedings under the Act including, inter alia, rules of Court respecting the fixing and awarding of costs.

The Master then awarded interim disbursements of $\$ 450.00 .^{11}$

Master Hyndman in Edmonton, in an unusual application by the husband for an order requiring the wife to post security for costs, said: ${ }^{12}$

By s. 10 of the Divorce Act, it is provided that the court may direct payment of interim alimony to either spouse by the other and by s. 11, maintenance by either spouse to the other. So, it appears that some realities of the 20 th century are here recognized, and while the Act makes no mention of costs, other than to refer to provincial Rules, it seems to me that as alimony and maintenance can now be awarded to be paid by a wife to a husband in a proper case, so likewise it surely follows that a husband's costs can now be awarded to be paid by a wife in a proper case.

In that case the wife, resident in British Columbia, had commenced two previous actions for divorce and three previous actions for judicial separation - all of which had never come to trial. It must be noted, however, that security was awarded under Rules 720 and 722, the wife being a non-resident in Alberta.

The Saskatchewan Rule 615 is similar to ours: ${ }^{13}$

615. The court may at any time, and if necessary from time to time, make such order as it thinks fit for payment of or security for the wife's costs.

The courts of Saskatchewan have recently held that their Rule provides that costs in a divorce petition are similar to all other costs - they are in the discretion of the court. ${ }^{14}$

In British Columbia, the Rule is as follows: ${ }^{15}$

30 (2) A Judge may at any time pending action, and if necessary from time to time, make an order as he thinks fit for payment of or security for the wife's costs, notwithstanding that the decision of the Court at the trial of the action is against the wife.

8 [1969] 1 O.R. 169.

9 Id. at 174 and 175.

10 [1970] 3 O.R. 289 at 290, 2 R.F.L. 85.

11 The writer assumes that the term "disbursements" is equivalent to the use of the word "costs".

12 Schribar v. Schribar (1969) 67 W.W.R. 349 at 351-352.

13 Sask. Rules of Court 615.

14 Olson v. Olson and Lazich [1971] 3 W.W.R. 506 at 516-517.

15 Divorce Rule 30, B.C. Reg. 154/68 (1968). 
In Joseph v. Joseph, Wilson J. discussed this question simply and directly: ${ }^{16}$

Neither the Canada Divorce Act or the Rules made thereunder create any change in the position of wife and husband as regards costs. The awarding of costs is in the discretion of the Court and it was formerly, as it is now, possible to make an order that a wife pay her husband's costs. . . .

As a matter of irrelevant interest, the British Columbia Rule was challenged, in the Joseph case, as being contrary to section 1 of the Canadian Bill of Rights, ${ }^{17}$ since it obviously discriminated in favor of the wife. The argument was rejected by Wilson J., both on the rather "chauvinistic" ground of the husband's common law duty to provide the wife necessaries, and, further, that under the Divorce Act, the duty to pay or provide costs was now reciprocal.

In the eastern provinces, where the attitude and philosophy towards divorce is rather reactionary, the old common law principle, as one would predict, seems to be in force. There appears to be no doubt that the wife's costs can be ordered or secured at any time. In Webber v. Webber, Limerick J.A. stated: ${ }^{18}$

The Divorce Act confers on the Court the authority to make rules relating to the awarding of costs. The authority is broad and is not restricted to costs of a successful party. The Divorce Rules provide for the awarding of costs to a wife payable by the husband before trial and up to any stage of the proceedings, a matter within the jurisdiction of the Court.

In Papp v. Papp, ${ }^{19}$ a reference was made to the Ontario Court of Appeal on the jurisdiction of the Master in Chambers to make an order in respect of interim custody of children under section 10 of the Divorce Act. Mr. Justice Laskin discussed the power of delegation by rule-making: ${ }^{20}$

I do not think that the conferring of original jurisdiction by delegation is a matter of procedure within para. (a) [of s. 19(1) of the Divorce Act], as it might well be if provision was made merely for a referral to the Master of issues upon which only the Court could make an effective pronouncement. Is then para. (e) [of $s$. 19(1) of the Divorce Act] wide enough to permit delegation to the Master of authority in respect of interim custody under $s .10(b)$ ? That the Master is an officer of the Supreme Court is on all hands agreed. The Divorce Act nowhere indicates the range or kind of duties with which officers might be invested; and, I can only read this part of para. ( $e$ ) [of s. 19(1) of the Divorce Act] as being a wide invitation to the Supreme Court to impose administrative duties upon the Master or other officers to facilitate the exercise of jurisdiction granted to the Court. But I do not think that judicial duties are necessarily excluded by s. $19(1)(e)$, especially when there is brought into account the sequential words 'any other matter considered expedient to attain the ends of justice and carry into effect the purposes and provisions of this Act'. What is 'expedient can take some coloration from practice in related situations. For example, the Master in Ontario has long had jurisdiction to make interim alimony orders, and recently this Court affirmed the Master's power to vary such orders: see Carvell v. Carvell, [1969] 2 O.R. 513, 6 D.L.R. (3d) 26. Dispatch is an end of justice as are fairness and impartiality, to mention other recognized attributes. ...

Accordingly, I hold that s. $19(1)(e)$ provides a basis for delegation by the Supreme Court, through rule-making, of power to the Master to make interim custody orders pursuant to $\mathrm{s}$. $10(b)$.

The Quebec Courts, in applying the Civil Code in conjunction with the Divorce Act, arrived at a conclusion similar to the case cited above. ${ }^{21}$ The Court in that case went so far as to hold that interim costs, having been ordered but not paid by trial, were nonetheless recoverable by the wife even though she was not awarded costs at trial. The reasoning was that interim costs were inevitably

16 (1969) 4 D.L.R. (3d) 646 at 649.

17 S.C. 1960 , c. 44.

18 [1971] 3 N.B.R. (2d) 94 at 96.

10 [1970] 1 O.R. 331, 8 D.L.R. (3d) 389.

20 [1970] 1 O.R. 331 at 340-341.

21 Ouellet v. Rousseau (1972) 6 R.F.L. 19. 
linked to interim alimony and once awarded cannot be taken away. However, if the wife had been awarded costs, the writer would suggest that the amount paid as interim costs would be, in all likelihood, taken into consideration in all jurisdictions.

It is therefore suggested that the new Divorce Act does not change the practice in Alberta or elsewhere in Canada as it existed previous to its passage. Indeed, it has evolved the right to interim costs so that either spouse, in a proper case, can successfully make an application, and the archaic exclusive right of a wife to apply for and obtain interim costs is now nearing a deserved end: ${ }^{22}$

The Victorians, one must remember, did not design their laws with the poor in mind. This fact is the one great weakness of the common law which sometimes makes it difficult to apply in the last decades of the present century.

In Walker v. Walker, ${ }^{23}$ the petitioning husband was a paraplegic and on welfare. The wife was also on welfare. In dismissing the wife's application for interim costs, Mr. Justice MacPherson of the Saskatchewan Queen's Bench was of the opinion that to award interim costs to the wife would preclude the husband from proceeding with his action as he could not pay the costs. This, he said, would shock our communal sense of justice". ${ }^{24}$ The assets of both parties must be looked at in arriving at a just conclusion.

In conclusion, it is submitted that the Divorce Act and Rules, as interpreted by the above authorities, allow no question as to the discretionary power of the Chambers Judge or the Master to grant interim costs in divorce actions to either spouse.

-LEONARD J. POLLOCK

22 Walker v. Walker (1971) 17 D.L.R. (3d) 638 at 639, 2 R.F.L. 87.

28 Id.

24 Id. at 639.

- Associate Professor, Faculty of Law, University of Alberta. 